\title{
Publiek domein en het belang van de overheid bij bodemsanering : een ongewasschen varken?
}

Citation for published version (APA):

van Maanen, G. E. (1990). Publiek domein en het belang van de overheid bij bodemsanering : een ongewasschen varken? Kluwer. https://doi.org/10.26481/spe.19900914gm

Document status and date:

Published: 14/09/1990

DOI:

10.26481/spe.19900914gm

Document Version:

Publisher's PDF, also known as Version of record

\section{Please check the document version of this publication:}

- A submitted manuscript is the version of the article upon submission and before peer-review. There can be important differences between the submitted version and the official published version of record. People interested in the research are advised to contact the author for the final version of the publication, or visit the DOI to the publisher's website.

- The final author version and the galley proof are versions of the publication after peer review.

- The final published version features the final layout of the paper including the volume, issue and page numbers.

Link to publication

\footnotetext{
General rights rights.

- You may freely distribute the URL identifying the publication in the public portal. please follow below link for the End User Agreement:

www.umlib.nl/taverne-license

Take down policy

If you believe that this document breaches copyright please contact us at:

repository@maastrichtuniversity.nl

providing details and we will investigate your claim.
}

Copyright and moral rights for the publications made accessible in the public portal are retained by the authors and/or other copyright owners and it is a condition of accessing publications that users recognise and abide by the legal requirements associated with these

- Users may download and print one copy of any publication from the public portal for the purpose of private study or research.

- You may not further distribute the material or use it for any profit-making activity or commercial gain

If the publication is distributed under the terms of Article $25 \mathrm{fa}$ of the Dutch Copyright Act, indicated by the "Taverne" license above, 


\title{
PUBLIEK DOMEIN EN HET BELANG VAN DE OVERHEID BIJ BODEMSANERING
}

Een ongewasschen varken?

\author{
REDE \\ uitgesproken bij de anvanding \\ van het ambt van gewoon hooglemaar in het necht; \\ in het bijzonder in het privaatrech \\ aan de Rijksuniversiteit Limburg \\ op vrijdag 14 septeniber 1990 \\ door \\ MR G.E. VAN MAANEN
}

KLUWER - DEVENTER - 1990 
(1) 1900, G.E. van Muanen, Mausrich

Alk rechen worbthouden. Niets wit dete vitgave mag worden verweelwoudigd, opgestagen in een weatu-

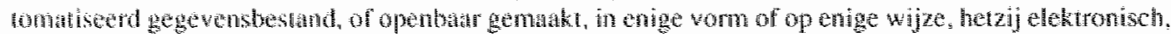
mechaniseli, door lotokopicon, opmamen, of enige andere manier, zonder vooralgaande schriftelilke toe. stemming wan de uitgever.

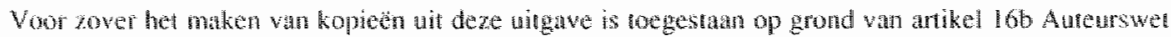

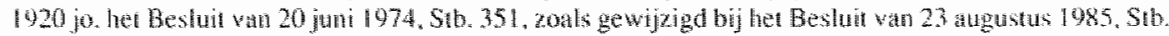

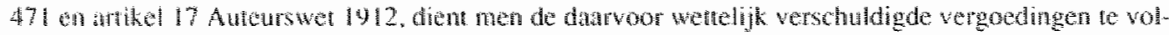
doen san de Stichting Reprorectht (Postbus 882,1180 AW Anvelveen). Voor het overnemen van gedeel-

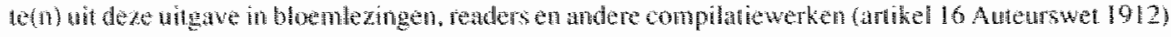
dien men zich wor de uigever te wenden. 
Minne heren leden van her College van bestuw.

Migneer de Recror Magnificus.

Dames en heren van her werenschappelijk corps.

Dames en heren van het onderstemend en beherend personed.

Dames en heren studenten.

en voorts Gij allen die mij door Uw canwezigheid bij deze plechighoid vereen.

Zeer gewardeerde tochoorders!

\section{EEN ONGEWASSCHEN VARKEN}

Zaken buiten de handel. Zaken die aan niemand toebehoren. Publiek domein. Welke jurist kan nog met enige nauwkeurigheid aangeven wat de positiefrechtelijke betekenis is van de rechtsfigutr (of rechtsfiguren) die met deze temen word angeduid? Verwarloosde en vergeten rechisbegrippen die nieuwe aandacht werdienen. Over de rechtsfiguur van zaken buiten de handel schreef Meijers reeds in 1918 dat het hier een materie betreft die zowel op publiekrechtelijk als op privaatrechtelijk lerrein ligt, waardoor zowel de publiekrechtelijke als de privaatrechtelijke auteurs haar hebben verwaarloosd.' Met alls gevolg dat dit varkentje - zo schrijt Meijers in een van zijn spaarzame luchtige beeldspraken - nog steeds niet is 'gewasschen' en dat dit varken nu toch wel erg ongewasschen rondloopt. Sinds deze woorden van Meijers is de situatie nief wezenlijk verbeterd en lijkt de belangstelling voor het publiek domein zelfs vrijwel verdwenen.

Waarom zou het van belang zijn om de rechrsfigurr van het publiek domein - ik gebruik nu verder di begrip? - nieuw leven in te blaren? Om in de sfeer van de beeldspraak te blijven: wat is de rechtvatadiging voor het reanimeren van ons ongewasschen varken?

Het antwoord hierop is - kort gezegd - het belang van een schoon milieu, cen schone lucht, schoon water, een schone bodem en alles wat daarin thuis hoort. Indien de overheid geen specifieke publiekrechtelijke regeling heef getroffen ter bescher-

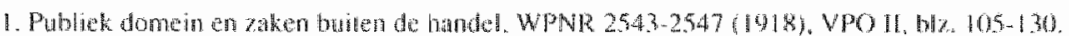

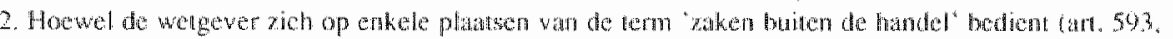

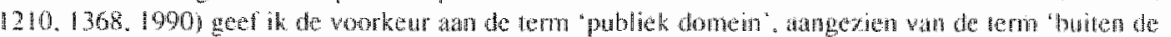

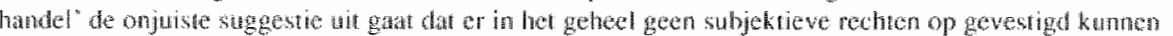

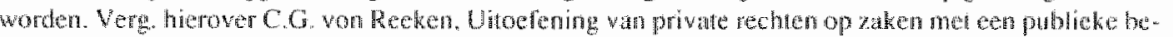

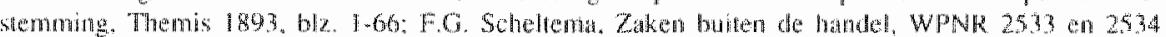

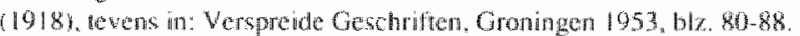


ming wan deze belangen en een privé weigenar onbrext lijk niemand zich de zorg voor deze belangen in rechte aan te mogen rekken. "Gelukkig is er de laatste jaren wen tendens da de overheid zich dit belang van een schoon milieu wel aantrekt. De burgerlijke recher honoreen in vel gevallen de stelling van de overheid dax zij verantwoordeligk is voor de zorg voor een schoon miliew. Een deugdelijke civielrechlelike fundering van deze stelling ontbeekt naar mijn oordeel veelal. Het bijna vergeten begrip wan het publick domein zou anknopingspunten woor een dergelijke fundering kunnen bieden.

\section{KOSTENWERHAAL, VOOR BODEMSANERING}

Ëen wan de grote problemen warmee we de latste decenna gekonfronteerd zijn is de verontreinging van het milieu, in het bijzonder var de bodem, met allerlei - al dan niet chemische - afvalstoffen. Lekkerkerk, De Volgemeer, iedereen weet waarover het gat. Niet alleen de bodem is op vele platatsen verontreinigd, maar ook de fivieren en andere oppervlaktewateren zijn zwar verwild gerakt. Naast preventieve matregelen is de overheid ook begonnen mer het saneren van de reeds vervuilde bodem en wateren. Een deel wan de hiermee gemoeide kosten tracht de overheid te verhaten op de verwiters, de latste tijd met enig succes."

De gebroeders an Amersfoort explofteren sinds jatr en dag een bedrijf warin metalen woorwerpen worden gegalvaniseard. Bij dit produktieproces komveel af valwater wrij. In de loop der jaren is daardoor een ernstige verontreining van de bodem opgetreden. Met toepassing van de Interimwet bodemsanering is de verontreirigde grond afgevoerd. Zowel de Stat als de provincie en de betreffende gemeente hebben hiertoe bijdragen verleend op grond van genoemde wet tot een bedrag van bijna cen half miljoen gulden. De Stat tracht vervolgens de schade te verhalen op de gebrocders Van Amersloort. Het bijzondere aan deze situatie is dat hier sprake was wan het vervulen wan de eigen grond, hetgeen de vaag doet rijzen warom dat ankiding zou kunnen geven tot ansprakelijkheid jegens de overheid.

Grondshg wan hel wethadstecht van de overheid zou kunnen zijn art. $1401 \mathrm{BW}$ (art. 6:162 NBW) in verband inet art. 21 Interimwet bodemsanering (1BS). de on-

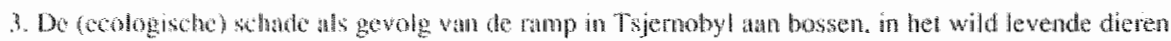

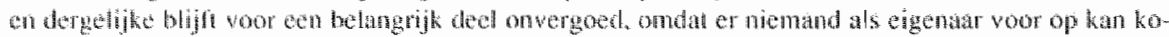

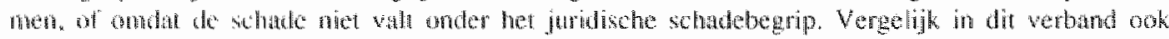

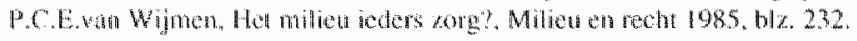

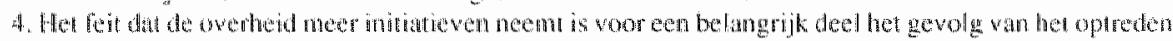

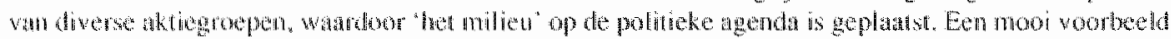

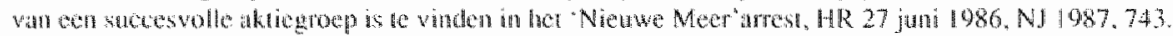

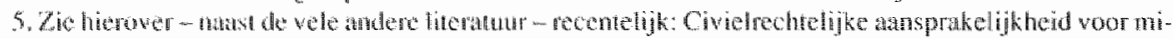

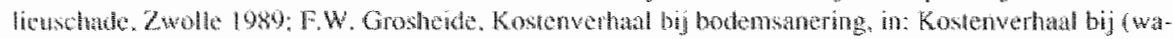

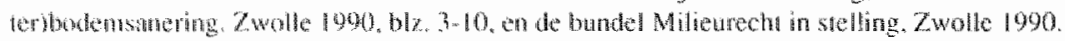


rechmatige daad van de vervuiler legenover de overheid. In de recente nitspirak van de Hoge Raad over deze kwestie? is vastgesteld dat emstige bodemverommenging onrechtmatig kan zujn tegenower de overheid indien de verviler ten lijde van het veroorzaken van de verviling wist of kon weten dat de overheid zich to zorg vour een schone bodem antrok of zou gaan antrekken."

Hoewel men met de uitkomst wan deze uitsprak wel gelukig kan zin is de gekozen konstruktie natr mijn mening onbevredigend. Het enkele feit immers, dat de overheid zich feitelik de zorg voor het milieu is gatu dantrekken en de kosten wan de sanering woor har rekening heeft genomen rechroardigt nog niet de konklusie dat de overheid dus een rechtens te respekteren belang had bijeen schone bodem. De gedachte dat het tegenover de Stat ourechtmatig is de boden te verontreingen ondat de overheid zich het belang van bodemsanering feitelijk anorekt, knoopt an bij het arres1 Gaasterdik-Zuidpool (HR 26 mei 1978. NJ 1978.615). Bij de parlententaire behandeling van art. 21 LBS word natr dit arrest verwezen teneinde awn te tonen dat het reeds geldend recht was om in dergelijke gewallen een onrechtmatige daad jegens de overheid aan te nemen. Meestal wordt dit arrest inderdaad begrepen ats een bewijs voor de stelling dat het enkele feit dat de owerheid zich een bupald belung had angetrokken voldoende is om or het rechtens te respekteren belang van die overheid op te baseren.

In dit arrest gat het er mijns inziens niet slechts on dat de overheid zich een bepaald belang had aangetrokken - i.c. de zorg voor de aanlooproutes naar de Westerschelde - maar tevens dat het hier gant om een taak, mamelijk de zorg voor de goede bevalibaarheid van de buiten de territoriale wateren gelegen atalooproutes natir een aantal grote Nederlandse havens, welke de overheid zich ook moest auntrekken." Te-

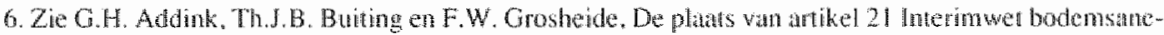

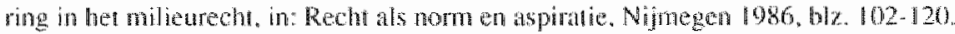

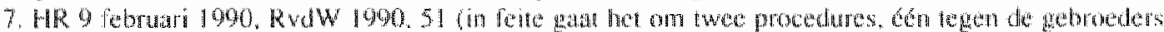

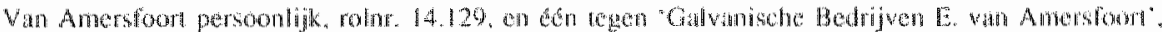

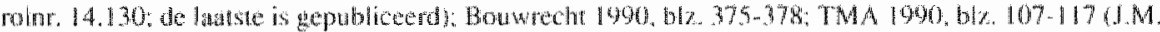
van bitmisy

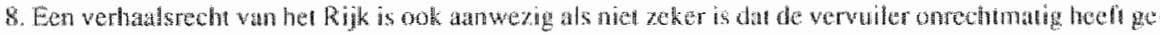

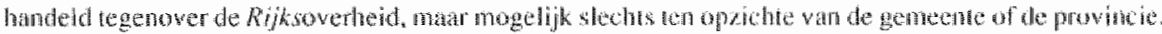

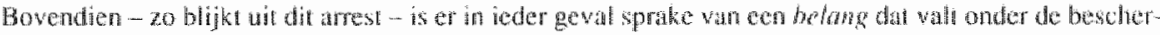

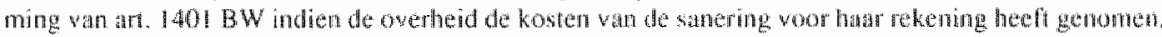

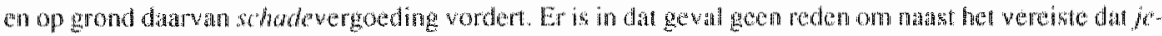

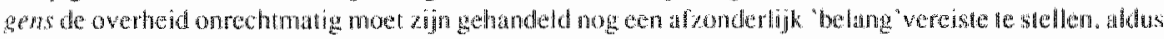

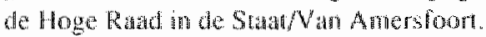

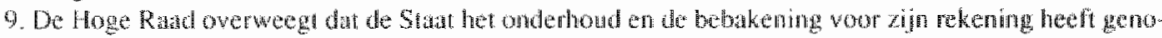

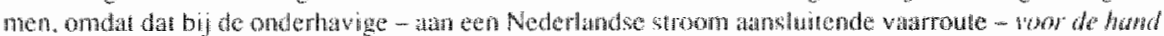

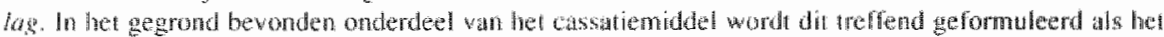

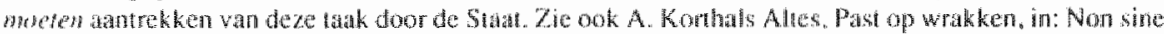

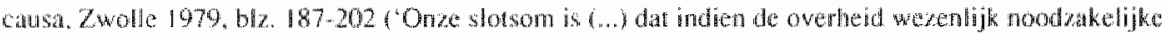

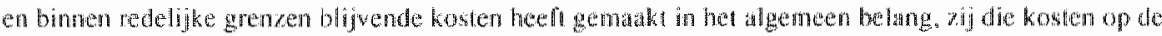
schuldige kan whalen"s. 
rech wordi deze zorgplich wan de Stat door Hardenbegg in werbund gebacht met art. 577 B W dar de Stuar he beheer van de "stroomen" opdraggt. Daarin ligt de recht streekse grondslag van het belang van de Staat en de plich die daaran verbonden is. De zorg voor de an hooproutes behoort nat mijn mening evenzeer tot het publiek domein van de Stad als de stromen zell.

Dat is de kem van dit arrest en niet slechts de konstatering dal de Staat zich dit belang ook feiteljk heft aangerokken. Dit laatste is onvoldoende om daarop het on rechtmatige van het gedrag jegens degeen die zich dat belang heeft achgetrokken, te funderen. Terech wijst G.S. Scholten er in zijn noot onder dit arrest op dat een bergingsrmatschappij die het wrak gat optumen zonder enige opdrach zich niet zonder meer op di arrest zou kunmen beroepen. Anders dan de Stad theeft deze niet als tak de zorg voor de aanlooproutes naar de "stroomen".

De Hoge Rad lijkt er evenwel in de zaak tegen de gebroeders Van Amersfoort wan wit te gat dat he feitelijk aan zuch trekken van het belang van een schone bodem door de Staat op zichzelf voldoende is om bij schending daarvan van een onrechtmatige daad jegens de Staat te spreken."

Dit oordee berust op en petitio principii redenering: de overheid heeff zich het mileubelang feirelijk aangetrokken en héfr betaald en heeft dus een rechtens te respekteren belang. Daarachter schuilt de fundamentele vrag waarom de overheid tot sanering over behoorde te gaan en de kosten daarvan te dragen.

Indien we uitgaan van de situatie warin iemand (niet zinde de eigenaar) schade toebrengt aan de grond van een ander is het niet moeilijk om de vraxg naar de grondslag van de onrechtmatigheid jegens die ander te beantwoorden; die ligt namelijk in de schending van het eigendomsrecht. In veel gevallen is het echter de eigenaar wan de grond zell (of diens rechtswoorganger) die varantwoordelijk is voor de vervuiling. zoals in het geval Van Amersfoont. En wan een onrechtmatige gedraging tegenover zichzelf kan men nu eenmaal niet spreken. ${ }^{2}$ De relativiteitsgedachte staat er voorts itan in de weg om bij een schending wan het eigendomsrecht door een derde reeds op die grond (ipso licho) van een onechmatige daad tegenover de Staat te spreken.

Wa kan dan wel dienen als grondslag van de vordering uit onrechmatige datad die de Stat pretendeent te hebben? In welk recht of in welk belang is de Stad ge-

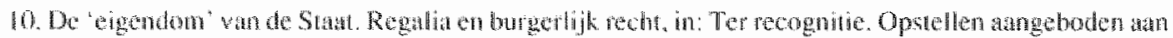

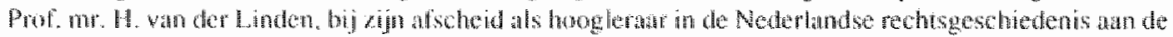

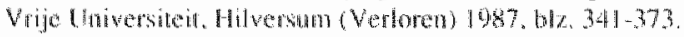

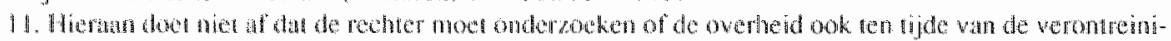

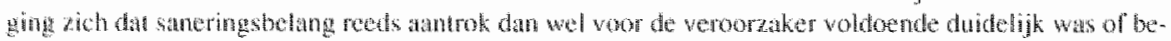

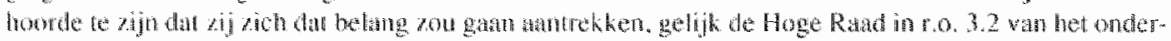

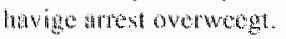

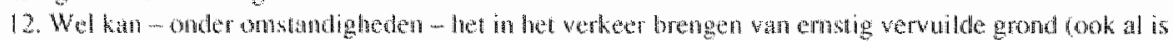

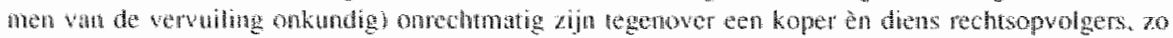

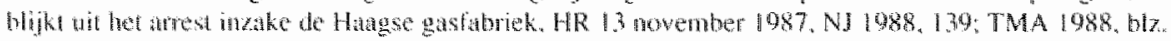

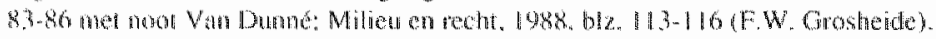


schonden? Laten we bij voorkeur niet viluchten in de wat al te genakkelike stelling dat het onzorguldig is tegenover de Stat om de bodem te vervulen "de vraag is immers watrom dat onzorgvuldig is en welk belang wan de Stant darmee gemoeid is." ${ }^{14}$

DE AARD VAN HET RELANG IN VERBAND MET DE ONTVANKELLKHED WAN DE EISER IN ZIN WORDERING

Voor zover een belang uitdrukkelijk wetelijke bescheming geniet in het Burgerlik Wetboek en de behartiging daarvan is opgedragen an de Stat cot een andere organisatie) ligt het voor de hand dat schending daarvan een aktie op grond van art. 1401 $B W$ rechvaradigt. Als het belang valu de Staat ligt in zijn recht op het publick domein (van bijvoorbeeld de openbare wateren) dan ligt het voor de hand om indien dit (subjektieve) rechr van de Statat wordt geschonden niet tevens de voorwarde te stellen dat de gedraging ook onrechmatig was jegens de Staat. Immens bij schen. ding van een subjektief recht hoeft de relativiteitseis niet (of nog ens) gesteld te worden, aangezien het verlenen van een subjekthef recht immers juist uitdruk dat er sprake is van een beschemenswardig belang. In het geval van publiek domein wordt aan de Suat de zorg opgedragen van het belang van velen bij een onbelemmerd gebruik - in velerlei zin - van het openbare water. Dit subjekteve recht is in zoverre bijzonder, aangezien het aan de Stat wordt gegewen als behartiger van de individuele belangen van velen.

Maar hoe zil het als er geen uitdrukkelijke regeling in de wet is? Welke belangen worden wel en welke niet door art. $1401 \mathrm{BW}$ beschermd?

Verburgh zier dit - in zin rede uit 1974 - als de kern van het probleem of de burgerlijke rechter mag oondelen over wat hij heeft genoemd 'kollektieve belangen'. Worden kollektieve belangen - zoak het belang wan een schoon milieu - beschermd door ant 140 l wan het Burgerlijk Wetboek? En - een vratg die door Verburgh niet witdrukkelijk an de orde werd gestald - mag de ovehëd darvoor ook bij de burgerlike recher bescheming zoeken?

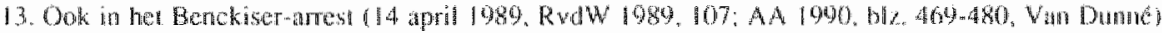

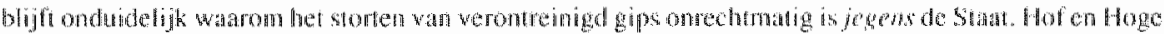

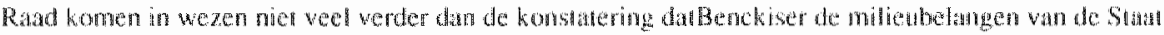

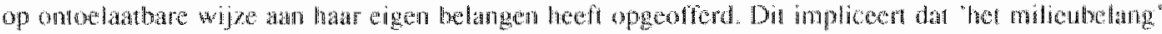

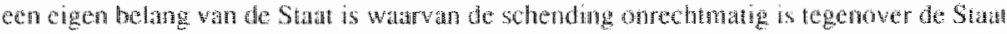

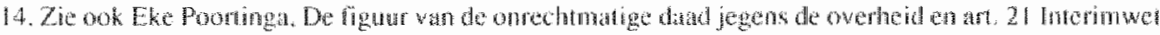

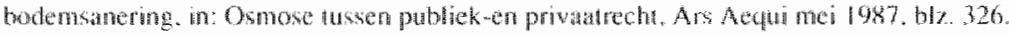

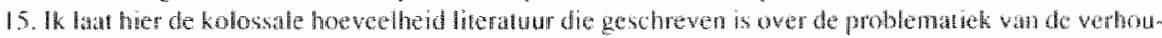

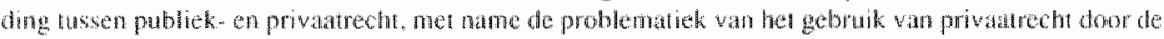

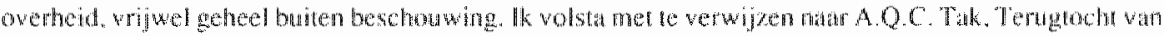

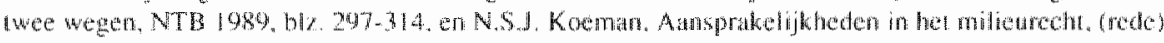
Deventer 1986 
Deze in wezen stoatsrechelijke vragen omtren de afbakening van de bevoegdheden van de burgerlijke rechter ter opzichte vari die wan de wetgever en het bestutr. komen in deze vorm naar voren omdat de bevogdheid van de burgetlike rechter op grond van ant. 2 RO geen wezenlijke drempel meer biedt, sinds het arrest Guldemond/Noordwijkcrhout. ${ }^{\text {sh }}$ De bevoegdheid van de rechterlijke macht om kemis te nemen van het geschil is afhankelijk van het recht waarin de eiser vraagt te worden beschermo en nief wan de aard van het recht waarop de verweerder zijn verweer grondt."

\section{WELEE BELANGEN VALLEN ONDER DE BESCHERMIRG VAN ART. 1401 BW?:}

Wat betreft de aard vam het belang waarvoor ant. 1401 bescherming kan bieden is sinds de rede van Verburgh in de rechtspratk meer duidelijkheid ontstaan. ${ }^{14}$ Uitgangspunt was het arrest Limmen-Houkoop ${ }^{\text {so }}$ waarin de regel werd geformuleerd dat het algemeen belang dat woor elk overheidshichaam betrokken is bij de naleving van de door dat licham uigevardigde wettelijke vorschritten op zichzelf net behoor! tot de belangen welke art $1401 \mathrm{BW}$ beoog! te beschermen.

Wel behoren tof de soort van belangen waarvoor art. 1401 bescherming bedoelt te bieden een storing van het woongenot en de clreigende sloop van woningen in de Zaandammerpolder."

Voor de vraag of het belang van de Staat, dal er op een zodanige wijze van de openbare weg gebruik wordt gemaakt dat er geen schade aan de weg ontstat, ook behoort tot de belangen die ant. $140 \|$ beoogt te beschemen, biedt het arrest inzake Rijksweg 12 (ook wel Kosten Waterstat) een belangrijke beslissing." In het cassatiemiddel was gesteld dat de op de Staat rustende plicht tot beheer en onderhoud zijn grondslag vindt in het publieke recht" en de op de Staat rustende plicht derhalve niet van privatrechtelijke aard was, zodat art. 1401 hier geen bescherming zou bieden.

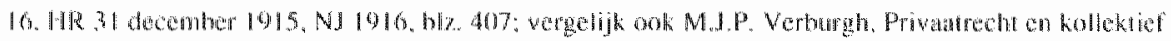

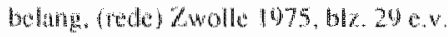

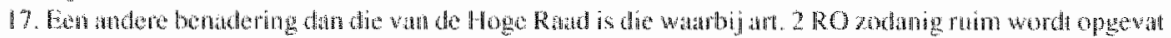

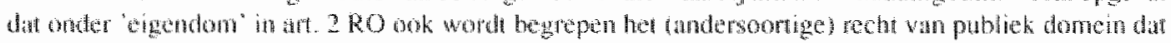

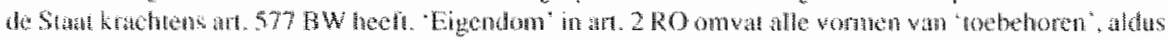

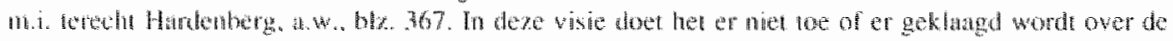

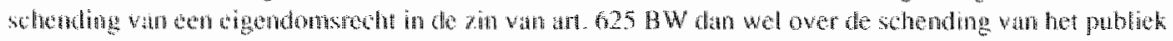

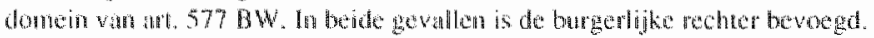

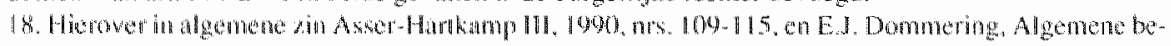

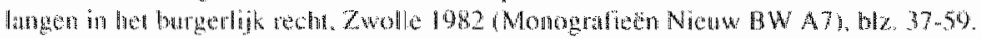

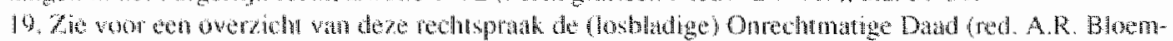

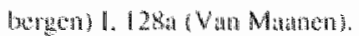

20. He nowember 1973. N 1974.91

21. H及 29 matat 1974. N1974, 344.

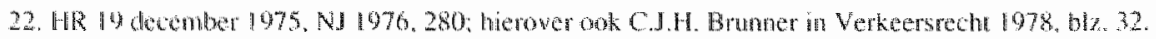

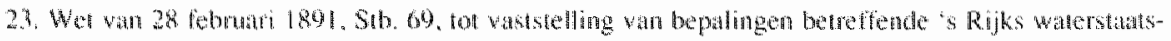
werked 
De Hoge Rad makt met dit argument korte metem er bestat geen reden om het belang warin de Stat in het onderhavige geval word gefroffen, niet re rekener lot de belangen die vallen onder de bescheming welke ant. 401 betoell to bieder.

Voonts overweegt de Hoge Rad da besturders van motorvoentugen ook tegenover de Stat, als belast met het behere en onderhoud wan do rifkswegen, verplicht zijn tou een zorgvuldig rijgedrag. Dawatan doet niet af dar de Stat dio matregelen in het algemeen belang on op grond wan publekrechelike voorschriften moet treffen:

Ook al gat het om matregelen die de Stat in het aggemeen belang moet memen en ook al zijn er publiekrechtelijke woorschriften die dartoe dwingen. dan nog betreft het een bolang wan de soon die wall onder bescheming van art. $1401 \mathrm{en}$ mag de Stat bij de burgerlijke rechter schadevergoding vorderen.

In hel licht van deze uitspraak is ook het reeds vemelde arrest inzake Gaasterdijk en Zuidpool niet zo verrassend meer. ${ }^{35}$ Op grond van deze uilsprask sial vast dat de Staat het recht heeft on de schade te verhalen op de reders wa de "Gaasterdik" en de 'Zuidpool' die met elkar in valle zee in anvaring waren gekomen, als gevolg warvan de Zuidpool in de bebakende varroute was gezonken. Niet nodig is dat or sprake is van een rechtsplich van de Stant to wrakopruming, woldoende is dat de Stat zich de zorg voor een goede bevarbarheid van de buiten de tertitoriale wateren gelegen aanlooproutes naar een antal grote Nederlandse havens heef moeten antrekken daar een redelijke vervulling van zin overheidstak dat meebuch.

Dat de bescherming van het milieu, in cast het voorkomen van het stoten van verontreinigde bagger uit de Amsterdamse grachten in de Niewwe Meer. en belang is dat valt onder art. $1401 \mathrm{BW}$, blijkt wit een daromtrent gewezen anest van de Hoge Rad uit 1986. Het hof had de vorderng van de milieuverengingen algewezen, met name omdat er niet sprake zou zijn van enig "concreet eigen belang dat zou ziju angetast". Naar het oordeel van de Hoge Raad behoren de hier an de orde zijnde belangen wel tot de soort die valt onder de bescheming die art. 1401 bedoelt te bieden.

Uit het recente Benckiser-arrest ${ }^{2}$ kan eveneens worden afgeletd dat hel belang van een schone bodem behoont tot de soort watrvoor arl. $401 \mathrm{BW}$ bescherming bedoelt te bieden. De Hoge Ratal legt her verband met art. 21 Grondwet - dat aun de owerheid de zorg voor de bewoonbarheid van het land en de bescheming en de verbetering van he leefmilieu opdragl - an me ant. 21 fnerimwet bodemsanering. De Stat is in beginsel herogd om zich in geval van dreigende schade and het milieu

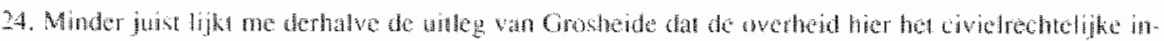

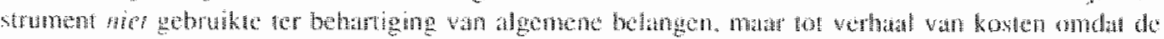

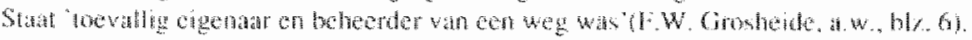

25. HR 26 mei $1978 . N 1978,615$

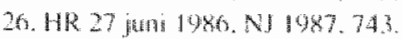

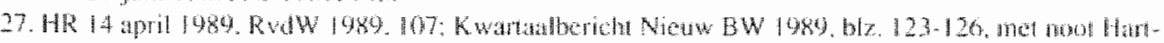

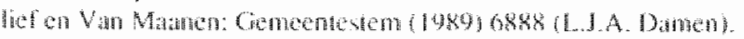


op grond van ar. 1401 tot de burgerlike recher te wenden, aldus de Hoge Rad.

Opmerkelyk in dit verband is het reeds genoemde arrest inzake Stadv foort, watin de Hoge Rad stell dat er voor het aftonderlij eisen van een door art. 1401 beschermo belang geen plaats is indien de overheid schade vergoeding vordert op grond van ean jegens had gepleegde onrechtmatige handeling. ${ }^{*}$

\section{STAND YANZAKEN IN DE RECHTSPRAAK}

De problematiek van het "140I belang" likt een ondoorcichtige warboel geworden. Van Dunné stelt zelfs voor on dit leerguk samen met dat van de relativiteit te verbannen naar een soon gesloten afdeling van de juridische biblioheck, waar slechts promowendi toegang toe zouden hebben. "wk wil her toch nog een poging doen enige orde te scheppen in de ontstane chaos. Mijns inziens vallen wit deze uitspraken de volgende konklusies te trekken:

- In beginsel mag de overheid ook gebruik maken war de privaatrechtelijke weg van art. 1401 in het kader van het beharigen van has publiekrechtelijke taak.

- De aanwerigheid win specifieke publikkrechtelijke regelgeving kan beperkingen stellen ande bewegdheid van de Staat om gebruik te maken van de civielrechelij. ke weg langs de burgerlijke rechter. Deze kwestie die aanvankelijk de problematiek van het 1401 -belang beheerste lijkt nu opgelost met de doorkrussingsformule."

Wat overblijft is de andere vraag, namelijk of het belang dat geschonden is behoort tot de soort belangen warvoor dit artikel bescherming beoogt te bieden. Daaromtrent staat nu in ieder geval het volgende vast."

- De zorg voor de bescheming wan het leefmilieu is in ieder geval een belang dat valt onder de soont warkoor art. $1401 \mathrm{BW}$ bescherming beoogr te bieden.

- Het is zeker ook een zorg voor de Stat.

- Ook al behoort het beharigen wan deze belangen tor de publieke plich van de overheid - zo blijk uit hel arrest Rijksweg 12 - dan nog kan de Stat daarwoon bij de burgerlijke rechter op grond van ant. $1401 \mathrm{BW}$ bescheming zoeken.

- Het is nio noodzakelijk dat deze zorg van de owerheid benst op een rechtsplicht (Zuidpool-atrest).

- Wanneer er (door de ovencid?) schadevergoeding wordt gevorderd is er in ieder

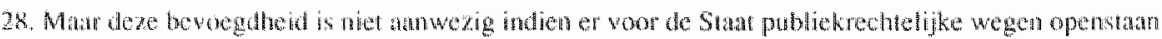

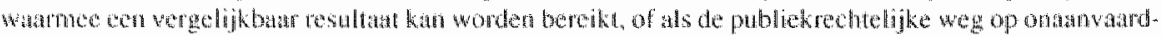

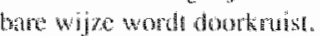

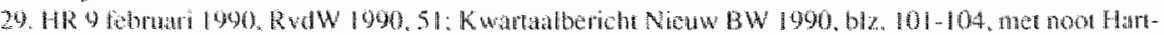
liet on an Mamen.

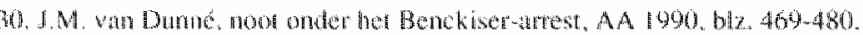

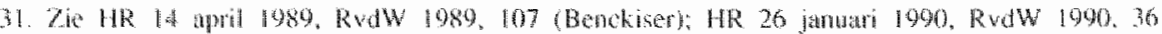

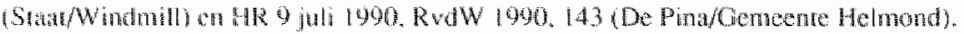


geval ean 1401 -belang, althans is dit een overbodige eis natst her relativeitsvereiste.

- Niet noodzakelijk is dat er sprake is wan de schending van een (subjektieb) recht van de overheid, yoldoende is dat er een belang is van de overtheid dat op onrechtmatige wijze wordt geschonden."

Dit betekent dat de burgerlike rechter atijd bevoegd en de eiser vrijwel altijd ontvankelijk is bij vorderingen tot vergoeding van milieuschade, ook als de Staat zelf als eiser optreedt." De publekrechtelijke regelgeving werzet zich slechts in een beperkt antal gevallen tegen de civielrechtelijke weg, namelijk als alternatieve bestuursrechtelijke mogelijkheden zijn die doorkruist zouden kunnen worden."

Opvallend is dat de twee uitspraken die het verst gan in het toekennen van een verhaalsrecht aan de Staat (Rijksweg 12 en Zuidpool) beide berrekking hebben op vorderingen yan de Stat als beheerder van het publiek domein, als rechthebbende op grond van art. $577 \mathrm{BW}$. Blikbarar is het belang warin de Staat daar word geschonden een bijzonder belang.

\section{VERVULLING VAN DE WATERBODEM}

Vervuiling van de waterbodem heeft tot nu toe - in juridische procedures - wat minder aandacht getrokken dan de verwiling van de nomale "droge" bodem. Maar ook hier gaal het om een probleem van gigantische omvang.

Verontreiniging van de waterbodem geeft aanleiding tot verschillende problemen. Het kan leiden tot onaanvardbare kwaliteitsvermindering wan het water, maar her kan evenzeer tot problemen leiden indien de verontreinigde waterbodem uitge-

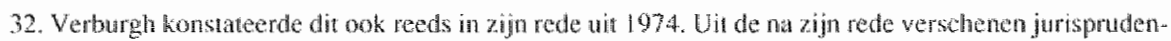

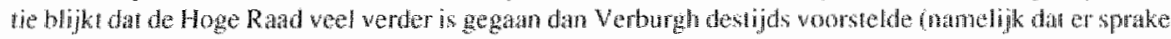

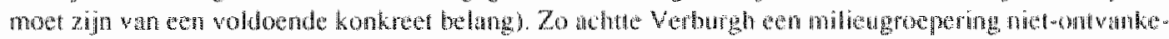

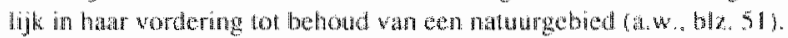

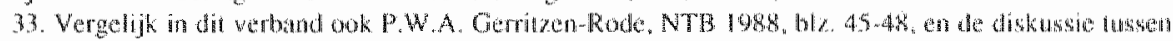

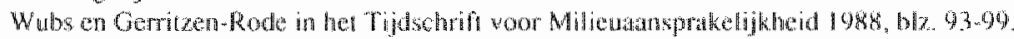

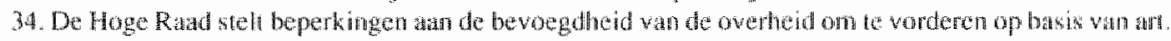

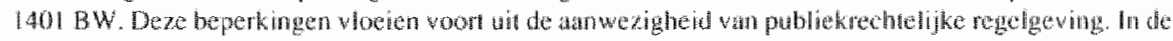

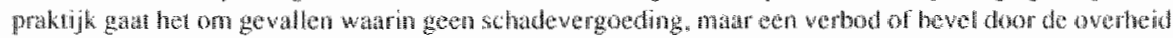

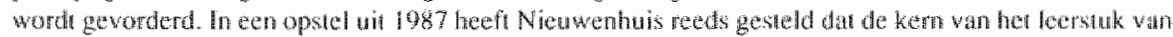

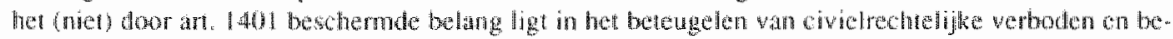

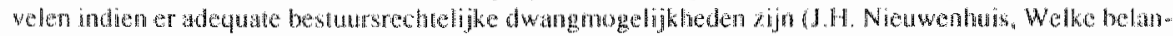

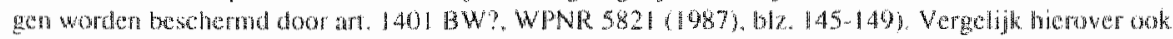

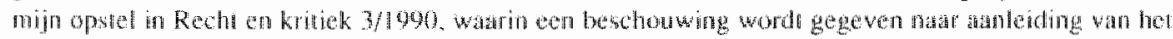

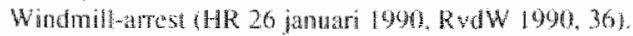

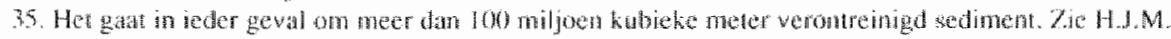

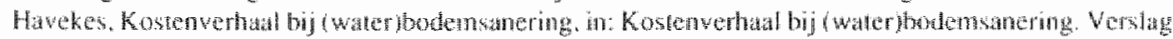

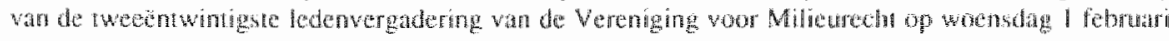
1989.7 whlle 1990, bin. 13. 
baggerd moe worden teneinde de vatweg op de vereste vardicpte te kunen houden. Het opslawn enfof remigen van deze baggerspecie leidt tot enome kosten.

Gesteld dat er sprake is van duidelijk aan wi gbare vervulers, dan ligt het voor de thand om ook his - al dan niel na ed sanering in hel kader van de Interimwet bodemsanering - ve truchten de schade op de veroorzakers darvan te verhaten.

Grondslag van de vordering wan de Stat tegen de verwiler is dat de overheid in hatur recht als beheorder van de warwegen, de stromen vit art. $577 \mathrm{~B} \mathrm{~W}$ is aangetas. De overheid word geschonden in harr recht van publick domem. "Het is duidelijk dat either spake is van een door art. $1401 \mathrm{BW}$ bescherno belang, angezien de wetgever dit belang als een reeht van de Stat heeft neergelegd in het Burgerlik Webock. Schending van dit recht van publiek domein is in beginsel onrechtmatig tegenover de Suat, net 20 als schending wan en elgendomsrecht in beginsel onrechmatig is tegenover de eigenat.

\section{DE Vookste STroom}

Deze gedachte is niet slechs van toepassing war het gaat om het gebrukstech van de bevaabsue en vlobare rivieren die kracthens art. 577 BW als publiek domein toebehoren an de Stad, matr geld evenzeer woor beken en rivierjes die niet bevarbatar zigh en derhave (positefrechtelijk) buiten het publick domein vallen. Voor hare niet-bevaarbare wateren stat een fradic bepaling in ons oude Burgerlijk Wetboek.

"Hij wiens eigendom gelegen is an den oever van een stroomend water, hetwelk nier tot het openbat domein behoort. mag wan dat voorbijlopend water tot bespoeling van zijn erf gebruik maken.' (art. $676 \mathrm{BW}$ ).

Dit recht van "bespoeling" omvat zowel het recht wan het gebruik wan het water om te irrigeren als ander huishoudehik gebruk, zoals bijwoorbeeld drenking van het vee. Dit rech wordt geschonden als een hoger gelegen oevereigenatr het water zodanig varvuil dat het voor een lager gelegen eigenaar onbruikbar wordt. aldus de Hoge Rad reeds in 1915 in de zaak van de Woorste Stroom."

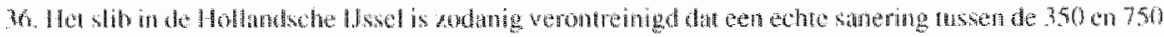

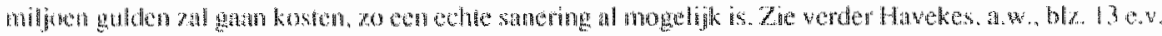

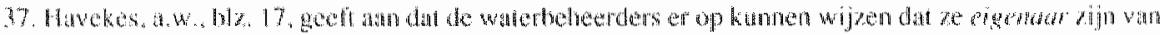

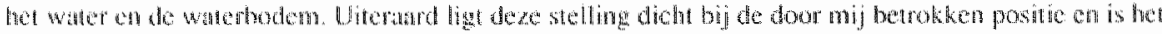

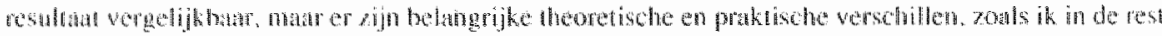

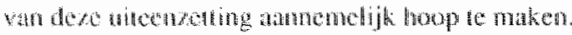

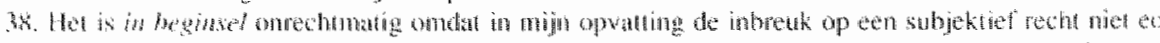

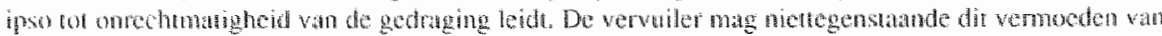

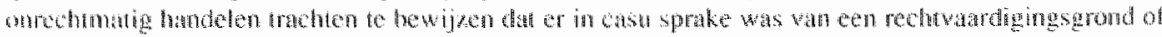

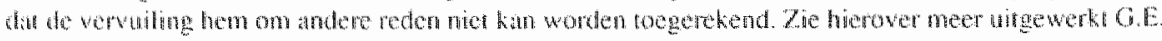

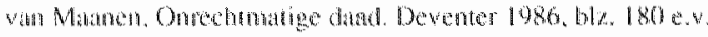

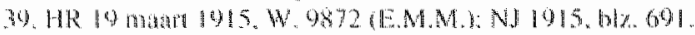


De gemeente Tilburg loosde per dag 20 "n 8000 kubieke meter atvalwater afkomstig van Tilburgse 'fabrieken, traficken en werkplatisen", waardoor the Holleman geschad werd in het recht om van het water van de Voorste Sroom gebruik te maken. De Hoge Raad zegt darover letrerlujk:

"dal het door de gemeente Tilburg darop afgevorde vull [reeds op zich zelf] voldoende is om den Voorsten Stroom te herscheppen in een stinksloot en het van nu ture zuvere water dier beek onbrukbar te maken voor mensch en dier". ledere oevereigenar heeft het recht dit water te gebruken voor allerter doeleinden, mits door dat gebruk andere oevereigenaren niet op bovennatge wije in hun gebruiksrecht worden benadeeld.

In dit arrest uit 1915 kon de Hoge Raad oordelen dat hiet sprake was wan een rech op schoon water van de benedenstroomse gebruiker. In het Kalimijnenartest van 1988 word gesproken van het belong van de benedensmoomse gebuiker van de Rijn." Her verschil voeit mijns inziens voort wit het feit dat de wet (in art. $676 \mathrm{BW}$ ) ten aanzien van de niet-bevaabare rivieren en beken an de oevereigenati een gebruksrecht tot (onder andere) bespoeling toekent, terwijl dat net betrekking tot de bevaarbare rivieren, behorende tot het publiek domein, niet met zoveel woorden het geval is."

Een en ander betekent dat het idee van een gebruik van het water door iedereen op zodanige wijze dat datardoor andere gebuikers niet in hun recht worden geschad. niet slechts terug te vinden is in de wettelijke regeling van zaken die expliciet als publiek domein worden angemerkt, maar dat dezelfde gedachte ook tor uitdruking is gebrachi ten aanzien wan de wateren die datriet (expressis verbis) loe behoren en die dus wel voorwerp van een gewoon eigendomsrecht kunnen $z$ ijn.

\section{WAT IS PUBLEK DOMEIN?}

Het word hoog tijd wat meer duidelijkheid te verschafen omtrut het begrip "pubhek domein'. Van oudsher wordt in het recherkend dal er zaken hijn die nier aan bijzondere personen individue loebehoren. mar die deel uintaken wan frel "bonum commune", zaken die van ons allemaal zijn en aun de Stat loebehoren." lets

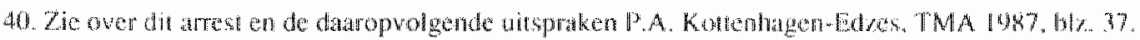

4. HR 23 sepember $198 \mathrm{~s} . \mathrm{N}] 1989.743$.

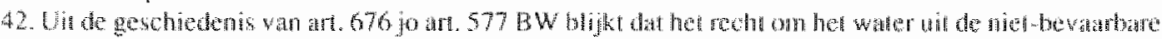

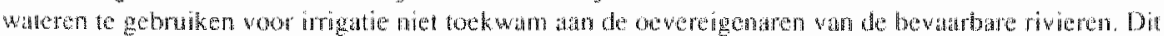

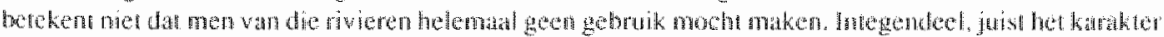

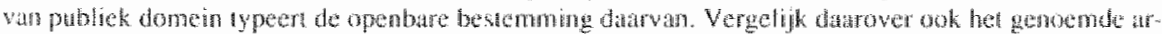
restan 1915

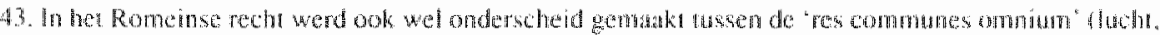

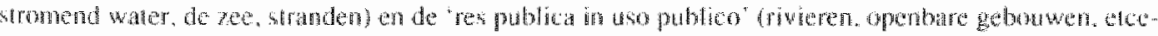


bethoort tot hel publick domein door 2 in bestemming ten algamene nute Deze bestemming kan of wal door de natuur gegeven zijn (denk aan de zee en de rivieren).

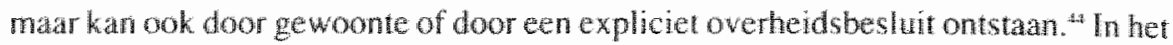
oude Burgenlik Wetboek wordt dit in an. 577 als volgly omschreven: "[Insgeligs] [A lan den staal [behooren] de wegen en straten, welke te zijnen laste zijn, de stranden der zee, de bevarbare en vlotbare stroomen ea rivieren met hunne oevers, de groote en kleine eilanden en de platen welke in die wateren opkomen. gelijk ook de thavens".

In een volgend artikel worden voorts nog vermeld "alle gronden en getimmerten welket "s lands vestingwerken behoren en gevolgelijk alle gronden watrop eenige werken van verdediging zijn aangelegd geworden, als: wallen, borstweringen, grachten, bedekte wegen, gacien" of vooruitspringende werken, pleinen warop krijgsgebouwen gesticht zijn, linien, posten, verschansingen, redouten, dijken, slui. $7 \mathrm{en}$, kanditen en hunne boorden".

In de art. 575 en 577 stat niet dat de Staat eigenaw is van al deze zaken, er wordt gesproken van "toebehoonen". "Mijns inziens terecht ondat het hier niet de gewone civielrechtelijke eigendom van ant. $625 \mathrm{BW}$ betreft, maar het publiek domein van de Stat. ${ }^{47}$ Een recht dat overeenkomsten èn verschillen vertoont met het gewone civiel-

teva). De terminologie was overigens niet enduidg. Zle W.O. Vagting. Publiek domein en zaken baiten den handel. Alphern a/d Rign, 1946, Hoofdsuk I.

44. Vergelijk hierover E. Poontinga, De scheiding lussen publick-en privatreche bij J.R, Thorbecke. Nij" megen $1987, b / 2.218$.

45. Astrigl woing op thet woorterein wan een fort.

46. In art. 579 en 5760 word wel - minder juish dunk mij- wan 'eigendon" gesproken. Zie voor een un werige inalyse L. Hardenberg, a.w. bly. 361 . Vergelijk onk de wetsgeschiedenis yan deze bepalingen bij Vegting, a.w. bly. I60 ex.

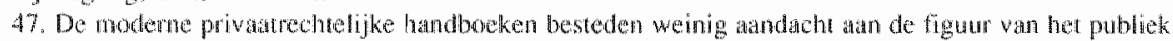
domein. Veelal wond onkend dat ar tegenwoordig nog spruke zou zin van een dergeligk publiek eigen-

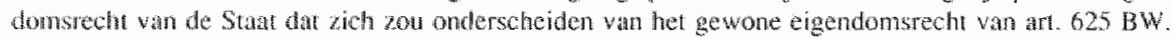

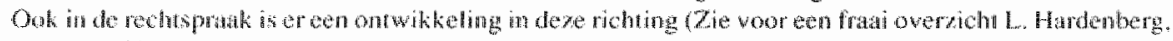

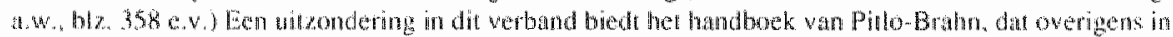

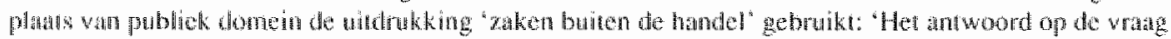

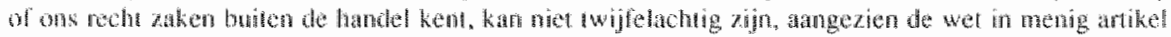

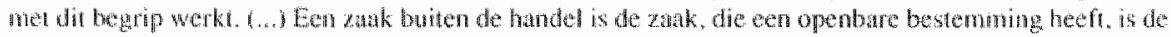

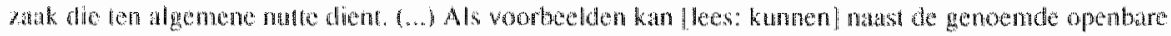
wegen on rivieren en vesingwerken dienen: depanernentsgebowen, provincie- en gemewtehuizen. Rijk bo gementenusea, havens, stranden, oorlogsmateriagl als geschut, munifie, do schilderijen in de

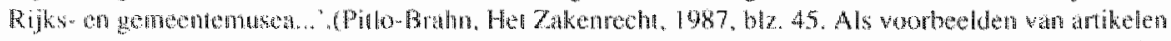

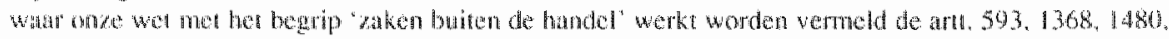

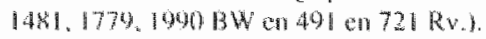

Ir Aswer-Bekhuis wondt hierover een andere mening verkondigd. Moet men dus annemen, dat de Stant

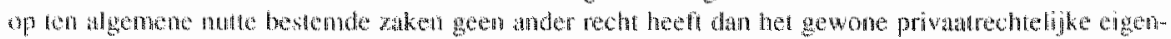

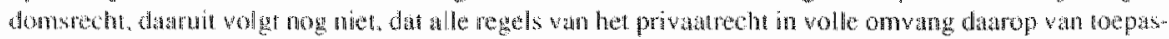

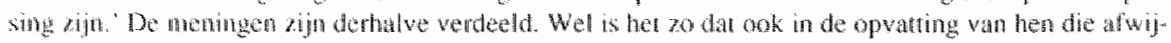

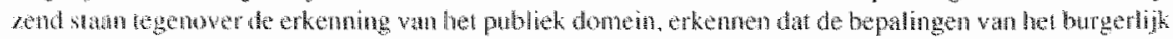

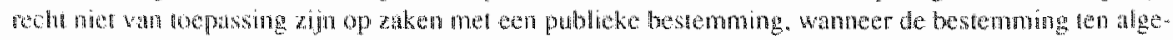

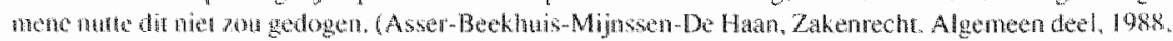


rechitlijke eigendomskoncept.

Hoewel het Nieuwe BW geen apante kategorie eigendom ondersched van zaten die an de Stat toebehoren, bhikt uit de Partemenaire Geschiedenis met betrekking tot de eigendom van de zeebodom dar bijvoobeeld de verveemding darvan slechts bij wet kan geschieden. In feite word ook daar met een ander vigendomsbegrip gewerkt.

\section{NEUW LEVEN YOOR EEN OUD BEGRIP}

Wat houd dit recht van publiek domein van de Stat in De bestemming van een zaak het algemeen belang te dienen brengt ean antal beperkingen mee die hat recht wan publick domein onderscheiden wan de gewone eigendom war art. $625 \mathrm{BW}$. Uit onze wetgeving bljkt dat het niet mogelijk geacht word dat derden door middel wan verkrijgende verjaring een eigendomsrech op zaken valtende onder het publiek domein kunnen verkrijgen. Beslag en bezit op die zaken zijn evenmin mogelijk." De publieke bestemming brengt ook beperkingen mee ten anzien van de verveemd. barheid van deze zaken."

Het publiek domein brengt mee een recht van 'beheer", maar ook een plicht tot "onderhoud" Kortom, een "publiekrechtelijke" staatstaak gekonstueerd ats een "subjektief recht' wan de Staat, maar geregeld in het Burgerlijk Weboek ${ }^{4}$ De strekking van art. 577 en $578 \mathrm{BW}$ is duidelijk: er zijn een aantal gemeenschappelijke belangen zoals de zorg voor een goede infrastruktuur en de landsverdediging die gemeenschappelijk behartigd noeten worden.

Betreft het hier nu een exklusief rech van de Stat, cen racht waar de burgers verder niets mee te maken hebben? Ik zou menen wan nied. Met name wathet betreft wegen en waterwegen heeft de burger een subjektief recht on van die gemeenschappelijke èn openbare wegen (een nomal) gebruik te mogen maken." Daarin onder-

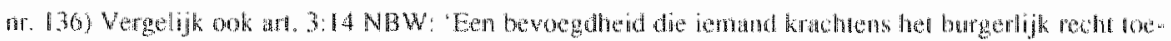

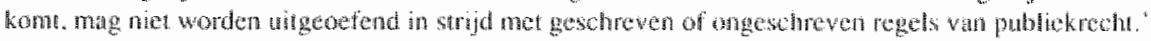

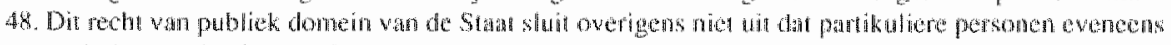

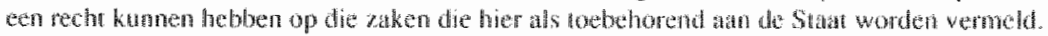

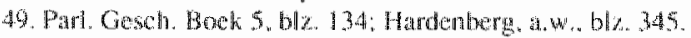

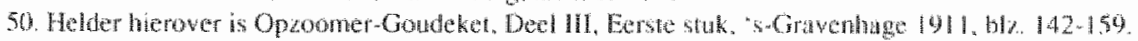

51. E.M. Meljers, a.w. biz. 100 .

52. Zie hiterower E. Meijers, 结, Bly. 115 e.w.

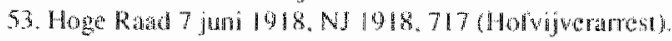

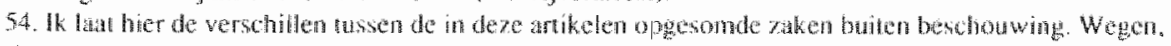

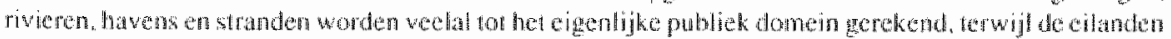

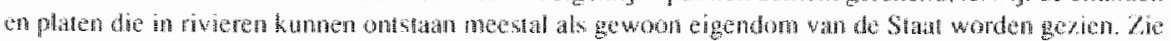

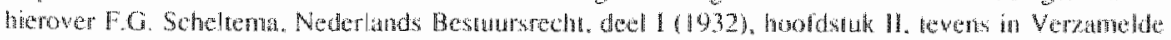

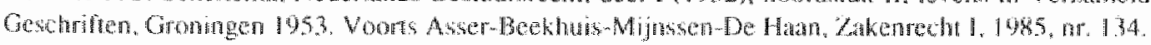

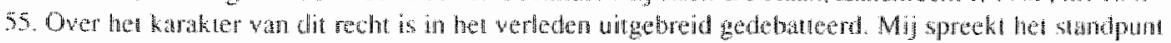

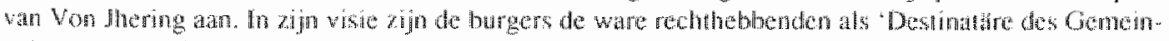

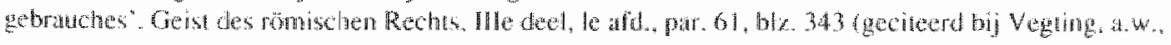


scheidt dif rechi wa publiek domen. zich op fundanentele wije van het gewone ciwirechelike eigendomsbegrip dat just gekenment word door het feit dat het de cigenar de bevogdheid geff om een leder ander van het gebruik van de zak warop dat rech betrekking heeft wit te stwien.

Warom is dit publeke elgendomstecht, dit recht wan publiek domein, in de vergetelheid geraki?

\section{PARTIKULIER EIOENOON TEGENOVER PUBLIEK DOMEN}

Narmate de publicke steer weherper onderschëden wordt van de privésfeer wan de burgerlijke matschappij - een tendens ingezet met de Franse Revolutic -- onlwikkelt rich steeds dudelijker het idee van en indwiduee leigendomsbegrip. In de loop van de 19 e euw word dit individucle eigendomsbegrip zelfs dominan en dreigt het idee van kollektieve eigendom, publieke eigendom in allerlei vomen, van gemeenschappelijke weiden tot en met hel publieke domein, als duidelijk andersoortige wormen van aigandom te verdwijnen. Eigendom wordt identiek met partikuliere eigendom $^{n}$

Hot ontstan van het modeme eigendomsbegrip hangt naw samen mat de - mede onder invloed van Thorbecke - doorgewoerde scheiding tussen publiekrechi en privantrecht. ${ }^{9}$ Dit heet tot gevolg dat het werschil hussen de publicke eigendom van de Staat en de privé-eigendom van individuen scherper naar woren komt. Uiteindelijk leidt dit ertoe dat wij tegenwoordig de publieke eigendom van de Staat nkuwelijks nog als een andere vom van eigendom herkennen. Wat traditioneel onder her pu blick domein werd begrepen word ofwel opgevat als gewone eigendom van de Suat, zij het beperkt door de publieke bestemning, ofwel losgemaak van het eigen domsidee en aangemerkt als onderdeel van de algemene publieke taak.

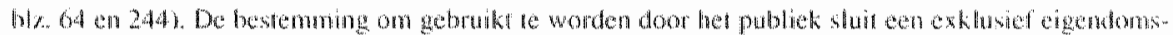

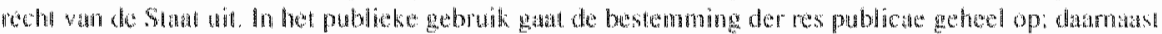

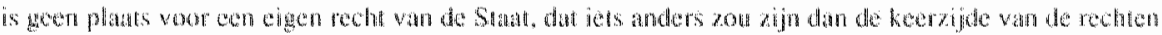

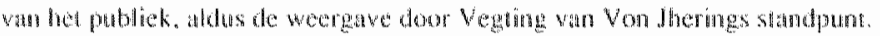

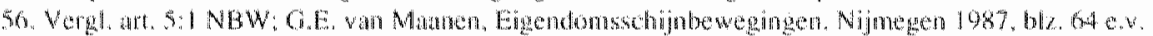

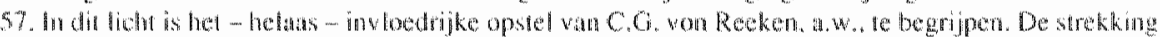

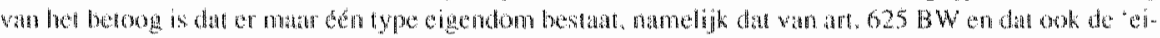

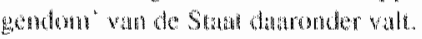

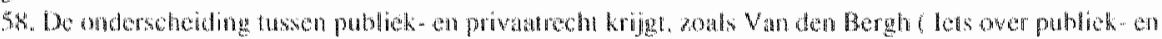

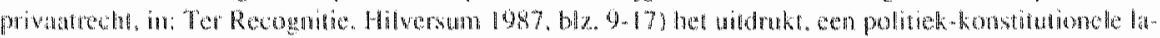

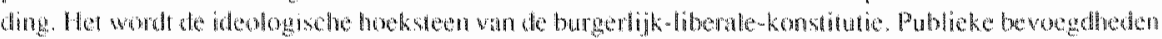

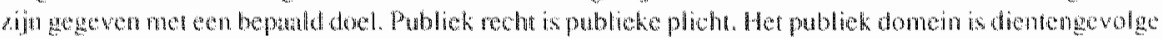

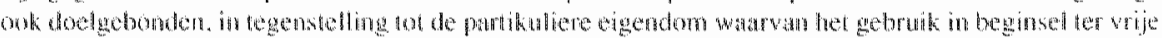

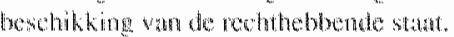

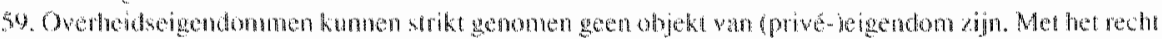

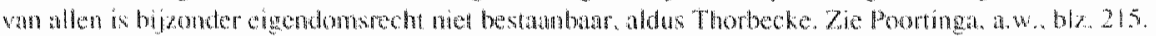


Voor zover het gaat om dic zaken warvan het gebruk atr allen gezamelijk toekomt, 20 ils bijvoorbeeld de openbare wegen, rivieten of de stranden. brengt dit doel mee dat een ieder het recht heeft op het gebruk datrwn, uiterand voor zover dat gebruk werenigbaar is met het gebruik dat en ander darvan wil maken. In essentie komt dut kollektieve eigendomsrecht dus neer op en recht om niev uitgesloten te worden van het gebruk van deze zaken; het partikullere eigendomstech be val dat. entegen de bevoegdheid om anderen juist wit te sluiten. ${ }^{\text {* }}$

Vanwege dit wezenlike verschil is het derhalve misleidend om ten amzien wan het publiek domein te spreken van een eigendomsrecht wan de Stut indian men daabij onder "eigendom" slechts verstat het "moderne" exklusieve racht zoals dat in art. 5:1 NBW te vinden is. Dit "moderne" elgendomsbegrip stat voor een relatio van de mens tot zijn zaken, waarbij de eigenaar voorgesteld wordt als heen en meester over het objekt van zijn recht, die naa eigen goedvinden - sommigen zeggen zelfs nar willekeur - daarover mag beschkken ${ }^{\text {s }}$ Een dergelijke opwatting kan dicnen - en heefl gediend - als ideologische legitimatie van een kapitalistische produktiewije, mat ypeert evenzeer de relatie van de eigenar tot de natum,

Het praktische verschil tussen de benadering van het publiek domein als "gewone" eigendon van de Staat en die warbij het publiek domein word gezien als en bijzondere vorm van toebehoren komt tol uitdrukking in de procedure die de Staat voerde tegen de gemeente Huzen. De Stat vordende dat de gemeente Huizen zijn afvalwater niet langer ongezuiverd op thet Issemeer zou lozen en baseerde zich darbij op de stelling dat Huzen inbreuk makte op het eigendomstecht van de Staat van het Isselmeer door dit wèl te doen. Volgens het hof was hier geen sprake van een gewom eigendomsrecht van de Staat, mawr van een publiek domein met een bestemming die meebrengt dat de gemeente Huizen gerechtigd is van het IJselmeer gebruk te maken om har riool water te lozen. In de visie van de Hoge Raad evenwel heeft de Staat ten aanzien van het 1 lsselmeer dezelfde bevoegdheden als krachtons art. $625 \mathrm{BW}$ aan iedere eigenar vin een on roerende zaak toekomen. Als eigenar is de Staat wrij om nat eigen inzich de darbij betrokken belangen af to wegen.

Hoewel de benadering van het hof mij principieel juister vootkomt dan die var de Hoge Raad is de uitwerking die het hot eram heet gegeven, naar mijn moning niet juist. Immers het recht wan de gemeente Huizen on - net als ieder ander-gebruik te maken wan het Isselmeer vind zijn grons darin wat het gebuik door de gemeene Huizen he gebruik van anderen - zoals vissers - zou bekorten. Het gebruk

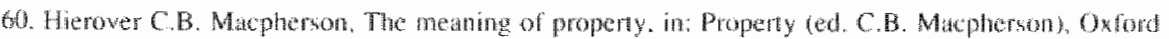
$1478.61 \%-13$.

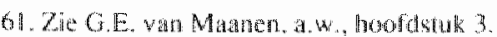

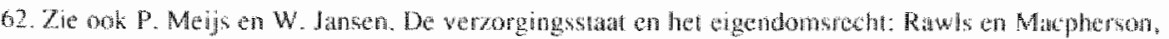

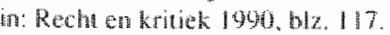

63. HR 19 Januar 1962. W 1962,151 (I.HB.). 
van hel recht om te lozen dient uiterard op de minst bezwarlijke wijze te worden witgeoctend.

Juist een benadering als publiek domein lat zien dat het gaat om een zaak war iedereen gebruik vin moet kumen maken en moet bliven kumnen maken.

\section{ZAKEN DYE AAN NIEMARD TOEBEHOREN}

Afgezien echter van de zaken die expliciel worden opgesomd als toebehorend aan de Shat, noemt art. 575 van ons oude burgerlijk Wetboek ook nog cen kategorie zaken die "aan niemand toebehoren".

"Yl est des choses qui n'appartiennent à personne el dont l'usage est commun it tous." In de Framse Code (art. 714) en de rechtsgeleerde kommentaren daarop zien we dat er expliciel op gewezen word dat het gebruik van die zaken (water, luchi) al. len gemeenschappelijk toekomt ${ }^{\text {th }}$ De overheid kan regels opstellen met betrekking tot dil gemeenschappelijke gebruik.

Het is fascinerend dat ook het Burgerlijk Wetboek de regeling betrefrende zaken "met betrekking tot derzelve bezitters" opent met de konstatering dat er zaken zijn die arn niemand toebehoren. De vogels in de lucht en de vissen in de rivier zin zaken die aan niemand toebehoren. Ze behoren aan niemand toe omdat ze - zolang ze in het wild lever - niet in bezit genomen zijn. Maar brengt dit mee dat ze claarom ook vogelvirilzinin?

Of zouden we kunnen stellen dat deze vogels en vissen en andere dieren en heel de flora en fauna die geen eigendom is van iemand in het bijzonder toch behoort $10 t$ het publiek domein en daamee tot de zorg wan de overheid, krachtens ongeschreven publickrecht, kirachtens hatar historische opdracht?

De noodzatk wan deze uitbreiding van de betekenis van het klassieke (wettelijke) begrip publiek domein tot zaken die aan niemand toebehoren blikt wit het feit dat het belang van het milieu op zich zelf - als zelfsandig belang - verdwijnt uil de furidische atweging bij de beoordeling van vorderingen tot schadevergoeding. In de proceduro tegen de Franse Kalimijnen. angespannen onder andere door een antal Westlandso tuinders, gaal hot om een afweging van het belang van de Kalimijnen bij de wervillende zout lozingen en het belang van de luinders bij een niet bovenmatig"

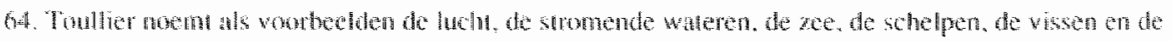

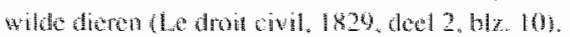

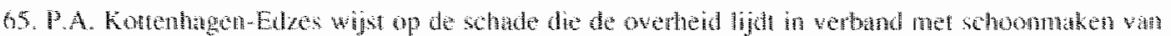

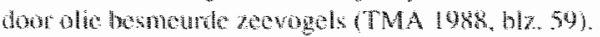

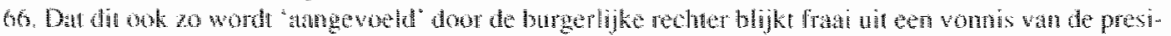

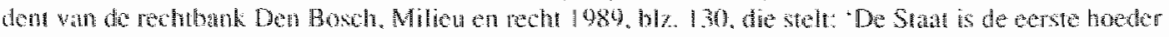

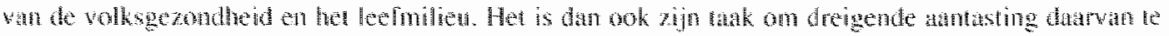

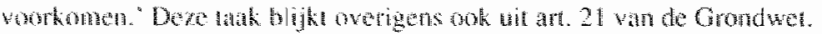


vervild sproeiwater. Het belang van een schone Rijn als en zelfstandig belang word niet in do afweging betrokken.

Ook de lucht die wij inademen valt onder de zaken die aw niemand toebehoren. Maar dat kan toch niet betekenen dat het toegestaan is om die hoht onbeperkt te vervulen omdat de lucht "van niemand is"? Een res mullus? Als we zien dat in het industriegebied van zuid-west Polen - Silezib - $90 \%$ wan de kinderen ademhalings moeiljkheden heeft en de kindersterfte wee mal zo thoog higt als in minder vervuilde gebieden, dan moet toch de konklusie zijn dat het niet just kàn zijn on de luch op te watten als iets wat an niemand toebehoort in de zin dat het een ieder vij stat om die lucht te verwilen? Nee, het is een zak die an allen gemeenschappelijk toebehoort. Het gebruik daarvan door de een mag niet ten koste gaan wan hel gebruik door de ander.

\section{VERHOUDAG TOT DE NATUUR}

De uibuiting van de ene mens door de andere. tot systeen geworden in het ontwikkelde kapitalisme, in het Oostblok voortgezet in nawm van het socialisme on het kommunisme, heeft - in beide systemen - zijn parallel in de uitbuiting van de nattuur. Het uitsluitend denken in termen van werkgelegenheid en groeiende industriste produktie gat ten koste van de natuur. De mens heef in deze opvating als heer en meester over de natuur het rech nat eigen goeddunken te beschikken over alles wal de naturu an rijkdommen biedt.

Het technologisch ingripen in de natuur via bio-technologio en genen-technicken leidt er toe dat het leven zelf voorwerp wordt wan intellektule eigendomstechten. Waar vroeger nog sprake was van een erkenning van een limiet aan datgene wat voor privé-eigendon vatbaar is ${ }^{\text {*ij }}$, lijkt er nu geen grens meer te bestaan ałn wat door de mens beheerst en in eigendom bezeten kan worden.

Deze erkenning van het in beginse! niet watbaar zijn voor privé-eigendom van zaken als de luch en de $z e$, de vissen in de rivier, de vogels in de lucht, dreig verioren te gaan en is al voor cen deel wertoren. Deze veranderde verhouding tot de natur - mede als gevolg wan nituwe technologische ontwikkelingen - komt ook op juridisch nivean tot undruking.

We zien dil ook met betrekking tor die zaken die traditioneel tot het publiek do-

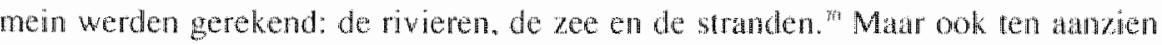

67. HR 23 serember 1988. No1989.743.

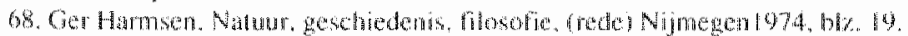

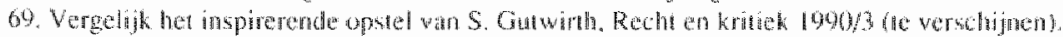

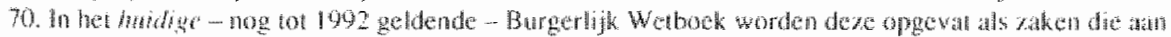

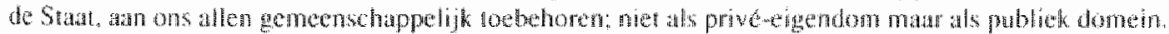

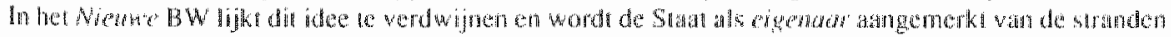
en de bodin man be zee. 


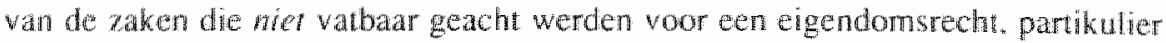
dar wel publick, verandert de verhouding." De zee mef mame de exploitatie van de zeebodem, word onder frat klinkende benamingen als het gemeenschappelijk erfdecl dermensheid, het geneenschappelijk patrimonim, voorwerp var exploilate. Antarchic wordt - zij het met allerlei watborgen - wrigegeven voor wetenschappelijke en technologische exploratie en explottatic. De cerste olierampen hebben zich ook daan al voorgedan.

Het is noodzakelijk om ta komen tot een erkenning wan een publiak domein, een sfeer wan kollekliewe belangen, warin uiteenlopende zaken zijn ondergebrach als de traditionele zorg voor openbare wegen en waterwegen, mat ook de wat minder tradionele belangen als die van een schone lucht en een schone bodem. ${ }^{3}$ Nier valt in te zien, watrom het vervulen wan water wel een shending van het publiek domein kan opleveren, mar het vervulen van lucht an bodem daar buiten zou moeten vallen." In de Verenigde Staten werkt men in dit verband met de "public urust doc. trine". In deze leer kan de overheid schadevergoeding vorderen in geval wan schade aan de natuurlike njkdommen watrover $2 \mathrm{j}$ het beheer heef. Vanut deze gedachte is er in de VS rederale wetgeving tot stand gebracht die de overheid de bevoegdheid geeft schadevergoeding te vorderen in gev at van schade an naturlijke rijkdommen die gean eigenar hebben."

\section{KONKLUSIES}

Het eigen-aardige van de rechtsfiguur van publiek domein is dat daamee tot uitdrukking wordt gebracht dat er kollektieve goederen bestaan, die enerzijds an de rechtsgenoten gebruikstechten verschaffen zoals ten aanzien van luch, water en bow dem $^{\text {to }}$, naar anderzijds dat het beheer darvan en de zorg daarover aan de overheid

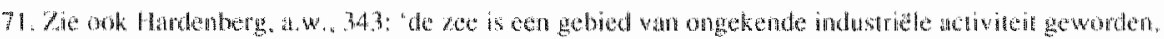

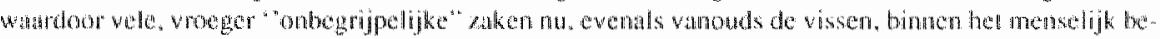

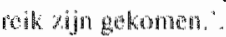

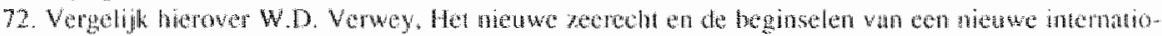

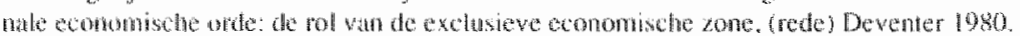

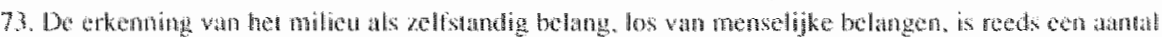

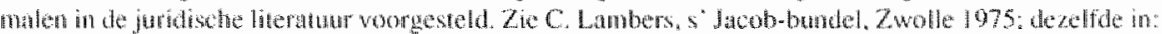

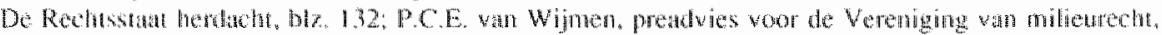

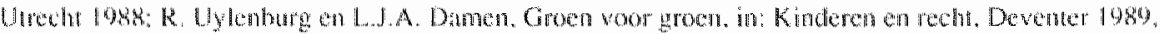

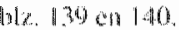

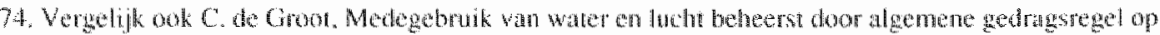
busis zan ar. 1401 BW. Miliea en nech 1987, bl7. 155-161.

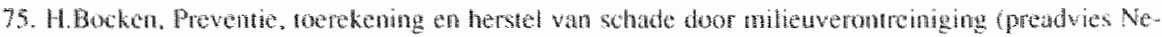

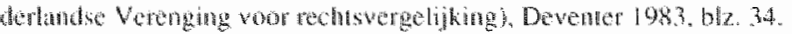

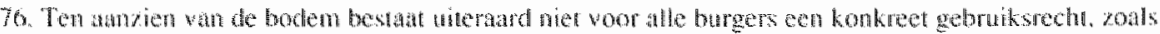

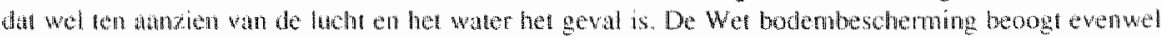

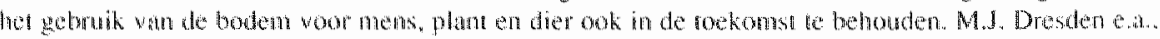


toebedeeld is. Anders dan het moderne exklusieve eigendomsbegrip is de kem van dit publiek domein het recht van alle rechsgenoten tot gebruik wan en loegang to het publiek domein."

Schending van dit recht is niet sleches in beginsel onrechtmatig tegenover andere gebrukers matr ook tegenover de overheid die immers het belang van alle gebrukers - nu en in de toekomst - behartigt. ${ }^{3 .}$

Omdat het gat om een (subjektief) recht vari de overheid is met de schending daarvan de onrechtmatigheid in beginsel gegeven. Hel is aan de veruillen om aan te tonen dat er in casu van onzorgvuldigheid zijnerzijds geen sprake was. De on rechtmatigheid van de schending van het gebruksrech van andere gebuikers is reeds tientallen jaren erkend in het Voorste Strom antest en recent bevestigd in de procedure tegen de Franse Kalimijnen.

Met betrekking tot vervuiling van de grond zijn er hoopvolle ontwikkelingen te zien in een aandal recente aresten, met name de procedure legen Vam Amersfoort." De erkenning van het recht op publiek domein in rume zin, dat ook het belang van een schone bodem omvat, kan de mogelijkheden van verhal in dagelijke gevallen vergemakkelijken en biedt nar mijit overtuiging een betere grondslag wan hel rech tot verhal wan de overheid dan tor duswere is gegeven. "Het is net slechts hei fei

$\rightarrow$

De We bodembescherming. Zwolte 1986 . Vepgelijk ook P.CE. van Wijmen, He milieu ieders zorg. Milieu en recht 1985, biz. 233.

77. Onder dil rume begrip publiek dome in vallen niet alleen de traditionele publieke eigandommen

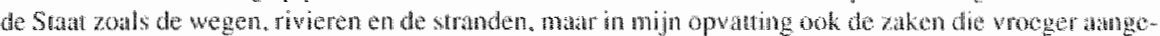
merkt werden als zaken die wan niemand toebehoren, zoals bigvoorbeeld de lucht. Matar ook valt datronder het rech op ean schone bodem. De grondeigenalar word derhalve in zijn bevoegdheid bepenkt door hel publiek donnein dat op die grond rust.

78. Deze konklusie kom oxereen - zij het op andere gronden-met de stelling vath Growhede, atw. bl. 10, dat het algemeen belang een rechtsbelang is dat in beginsel door oveneid en partikulieren met behulp wan hel civiele ansprakelijkheidsrech kan worden beharigel.

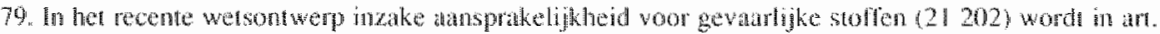

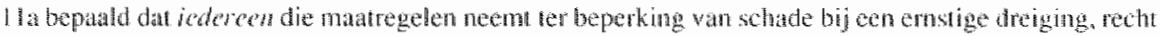

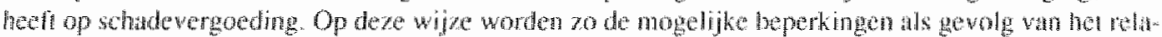

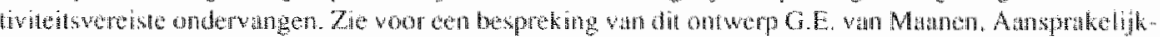

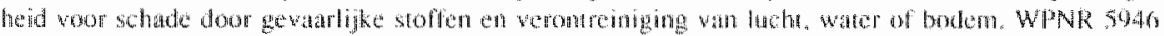

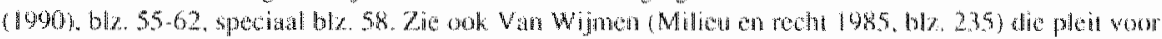
een onkering wan de bewijskast.

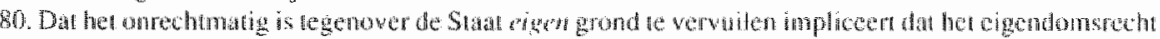

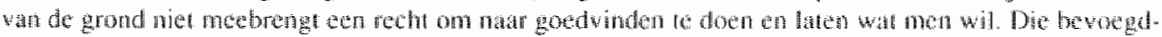

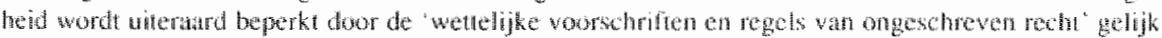

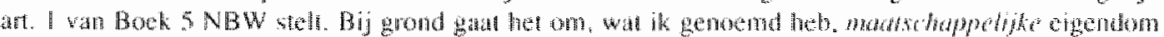
(Eigendomschinnbewegingen. biz. 157\%.

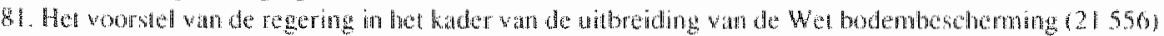

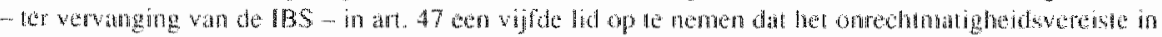

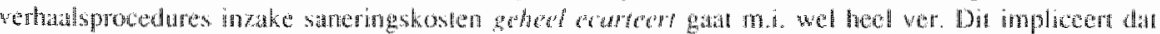

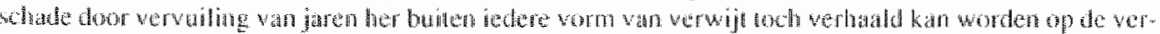

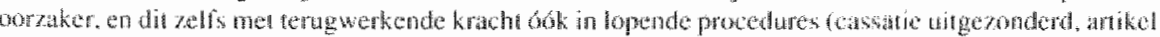
vit.

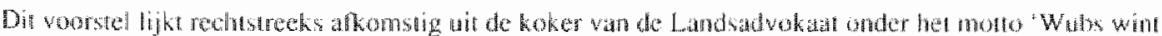

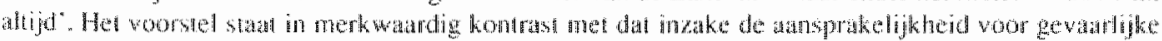


dat de owerteid zich de zorg voor een schone bodem, een schoon milieu is gadan antrekken, mat ook dat de overheid dat gegeven had opdracht als behartiger van het publiek domein ook moent down.

\section{HET VARKENTE GEWASSCHEN?}

Aan het einds wan deze rede gekomen, kom de vradg op of het varkentje waraver Meijers in 1918 sprak - de wat onduidelike status wan het begrip publiek domeinnu inderdadd gewassen is? $k$ zal niet zeggen dat dat duidelijk het geval is, daarvoor is de problenatiek ook te omwangrijk en komplex woor het beperkte kader van een rede als deze; wel hoop ik te hebben laten zien dat het de moeite ward is on dit oude begrip nog niet weg te gooien. Ook onder het Nieuwe BW blift het en belangwekkend (analytisch) rechsbegrip. Zoals Mejers het treffend heeft verwoord:

"Zulfs echter, indien thans practisch de betekenis der wettelijke voorschriften van zaken buiten de handel gehecl onbrak, dan nog zouden zij een theoretisch bestaansrecht hebben; zij zijn de uitdrukking der waarde, die aan het ten algemeenen nute bestemde gemeenschappelike eigendom van het wolk wordt toegekend".

Dut ons varkentje nog niet helemaal schoon is is wellicht wel zo milieuwriendelijk: aen scharelvarken hoort toch een beetje onder de modder te zitten?

Het is een gebruikelijk ritueel om na het witspreken wan een openbare rede bij de aan. warding valu het ambl van hoogleraat ean aantal leenneesters te bedanken. Ik wil dat niet doen. Ik erken geen leermeesters in de zin wanth dit woord veelal gebrikt word, namelik in de betekenis van ondergeschik theid van de leerling an de mees. ter. Ni dieu ni maître.

Wel zijn em een aantal personen met wie ik op voet van (all dan niet vermeende) gehjk wardigheid heb mogen debatteren, varn wie ik veel geleerd heb en aan wie ik veel verschuldigd ben.

Ik noem de huidige an vroegere redakteleden wan Recht en kritiek, die wollich de betangrijkste rol bij min "intellektuele" ontwikkeling hebben gespeeld. verder wiremand Brumer, mijn pronotor, van wie ik heb geleerd hoe jurshen denken, en Brahn, wiens vriendschap altijd hartvarwamend is geweest.

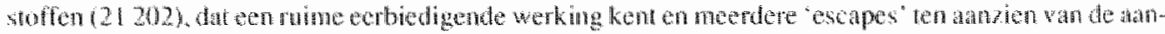

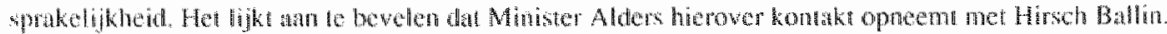

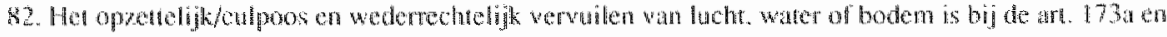
b) Wus statorat gesteld.

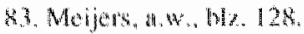

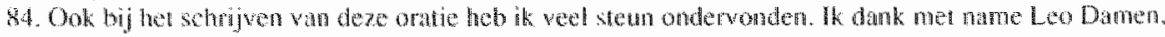
Fhe Pooringa, Roel de Lange an Ton Hatiel.
} 
Mijn fillosof"sche scholing dank ik vooral aan Ger Harmsen, Lolle Nauta Ulli d"Oliveira, Damiaan Meuwissen en John Griffiths.

Dat ik me er op verheug de samenwerking met iedereen in de Maastrichtse Fakulteit. met name ook met mijn naaste kollega's René de Groot en Kid Schwarz, op dezelfde prettige wijze voort te zetten als tot nu toe het geval was, behoeft naar ik hoop nau welijks belloog.

Ik ervaar het als een uitdaging om de aanpak van Jacques Elders - die zich niet beperkte tot een strikt positiefrechtelijke benadering - voort te zetten en hoop zowel in civielrechtelijke als in rechtsfilosofische zin in zijn voetsporen te treden. 